\title{
Lessons From the Twin Mega-Crises: The Financial Meltdown and the BP Oil Spill
}

\author{
Hershey H. Friedman and Linda Weiser Friedman \\ City University of New York, United States
}

\begin{abstract}
This paper explores the synchronicity of two mega-crises we are now facing: The BP oil spill and the repercussions of the 2008 financial meltdown. It examines some key common threads in both of these crises. The overarching message is that firms must maintain a culture of social responsibility, must behave in an ethical manner, and must do everything possible to avoid societal harm. The three key lessons to be learned from the twin crises are to consider and mange risk in decision making; minimize conflicts of interest in the hope that executives will then not engage in actions that involve excessive risk to stakeholders; and that government regulation can be beneficial, rather than harmful to business and society - as long as it does not stifle innovation and growth.
\end{abstract}

\section{Keywords}

Risk management, social responsibility, societal harm, ethics, conflict of interest

\section{Introduction}

In recent decades, several crises have buffeted the United States economy. The savings and loan debacle of the 1980s and 1990s, which cost American taxpayers $\$ 124$ billion and led to the failure of more than one thousand banks, was followed by numerous corporate scandals, at such firms as Enron, Adelphia, Global Crossing, WorldCom, and Tyco International, involving accounting fraud and financial irregularities. The Sarbanes-Oxley Act of 2002 was enacted as a reaction to these problems and to restore confidence in our economic system. Then in 2008, the largest Ponzi scheme in history, perpetrated by Bernard Madoff, made it apparent that our financial system was still not being monitored properly.

The above crises are nothing compared to the two mega-crises the United States is facing today: The financial meltdown of 2008 and the British Petroleum (BP) oil spill. The financial meltdown of 2008 has cost millions of jobs and trillions in assets. It will take years for the U.S. - and much of the world - to recover completely from this financial crisis. The BP oil spill is the worst in American history with about 5 million barrels of oil - a figure which translates to more than 200 million gallons of oil -

Copyright (C) 2010 Victoria University. This document has been published as part of the Journal of Business Systems, Governance and Ethics in both online and print formats. Educational and non-profit institutions are granted a nonexclusive licence to utilise this document in whole or in part for personal or classroom use without fee, provided that correct attribution and citation are made and this copyright statement is reproduced. Any other usage is prohibited without the express permission of the publisher. poured into the Gulf of Mexico (Robertson and Krauss, 2010). It is even worse than the Ixtop oil spill of 1979-1980, which resulted in 139 million gallons of oil in the Gulf of Mexico. The damage caused by the BP oil spill will be in the tens of billions of dollars, and will be felt for many years to come.

Each of these cataclysmic failures is being studied separately, and in depth. The 
experts want to know what went wrong and what, if anything, we can learn for the future. It can be even more interesting to look at them together. Is it just the randomness of the universe, a coincidence of chronology, that brought these two mega-crises together on adjacent pages of our daily newspapers (and web sites and news programs)? Or, can we actually learn something from this apparent synchronicity? That is the question addressed by this paper.

\section{Risk Management}

The major difference between a thing that might go wrong and a thing that cannot possibly go wrong is that when a thing that cannot possibly go wrong goes wrong it usually turns out to be impossible to get at or repair (Adams, 1992, pp. 137-138).

One reason that econometric models often fail may be that they cannot account for every contingency, especially those with extremely low probabilities. Taleb (2010) developed the Black Swan Theory to explain the importance of very-low-probability events in finance, history, and technology. Because these events have extremely low probabilities they can almost never be predicted accurately by models; also, people tend to ignore them since they appear to be impossible. Unfortunately, black swan events are not impossible and happen more often than we think. For example, who could have predicted Hurricane Katrina, 9/11, the bankruptcy of Lehman, the BP oil spill, etc.? Rogoff (2010) makes the point that it is quite difficult for companies to "strike a balance between managing 'tail risk' - a very small risk of a very large disaster - and supporting innovation" (para. 8).

In manufacturing and operations, one way of reducing risk, even low probability risk, is with redundancy. Most airlines understand that passengers do not wish to risk their lives flying. While the probability of an airline pilot becoming incapacitated while flying a plane is very low, still, the government requires that airlines place a co-pilot in the cockpit. Similarly, jets have two engines; if one fails, the other serves as a backup. Of course, too much redundancy can cause its own problems. A jet with six engines would probably be more dangerous than one with two because of increased complexity and weight. Also, with redundancy involving people, each individual counts on someone else to make sure nothing goes wrong; no one takes responsibility. Redundancy can cause people to take big risks. There is a science to risk assessment and management. The goal is to make a system reliable and to manage risk. It is important to anticipate all the things that can go wrong. Also, it is important to have several ways to accomplish the same task, such as shutting down an out-of-control system.

When does it become important to monitor and manage risk, even the risk of things that "cannot possibly go wrong"? For both BP, and by extension the oil industry, and the financial institutions involved in the recent crises, the best answer is probably - before disaster occurs. Too late now, of course, but this begs the question(s) - could these mega-disasters have been averted? And, what can we learn for the future?

Historically, BP has had a very poor safety record, worse than most oil companies (Mouawad, 2010). According to experts in the oil business, BP has a history of taking too many risks, cutting corners, and skimping on safety in the service of higher profits and growth (Lyall, 2010). Some previous problems include a March 2005 explosion in a Texas City refinery owned by BP - 15 people died and 170 were injured. The facility was very old (built in 1934) and was not maintained well. An investigation by the U.S. Chemical Safety Board concluded that the explosion was caused by "organizational and safety deficiencies at all levels of BP" (p. A14). More than 300 safety violations were discovered at the Texas refinery and BP was fined \$21 million - a record at that time.

The Thunder Horse oil platform in the Gulf of Mexico almost sank in 2005 in the aftermath of Hurricane Denis; it was actually tilting very ominously. The problems were due to a total disregard for safety. Some of the problems that were discovered included a check valve that had been installed backward and pipes not welded properly. There could have been a horrific oil spill at Thunder Horse, had the well been active. BP has had additional problems at its Ohio oil refinery (62 violations) and a 200,000 gallon oil spill on May 25, 2010 in Alaska (Lyall, 2010). BP had another crisis in 2006 when 267,000 gallons of oil leaked from their pipelines in Alaska. Investigators found that the cause of this oil spill was poorly maintained pipes that were corroded. The company did a very inadequate job of 
inspecting the pipes on the North Slope in Prudhoe Bay, Alaska. BP had to pay more than $\$ 20$ million in fines and compensation (Lyall, 2010).

Representative Bart Stupak of Michigan said the following regarding BP: "It is a corporate problem. Their mentality is to get in the foxhole and batten down the hatch. It just seems there is this pattern" (Mouawad, 2010, p. A22). Henry Waxman, Chairman of the House Energy and Commerce Committee, felt that "BP cut corner after corner to save a few million dollars here and a few hours there" (Lyall, 2010, p. A14). And David Michaels, OSHA administrator, had the following to say about BP (Lyall, 2010):

\begin{abstract}
Senior management told us they are very serious about safety, but we observed that they haven't translated their words into safe working procedures and practices, and they have difficulty applying the lessons learned from refinery to refinery or even from within refineries ( $p$. A14).
\end{abstract}

It may be hard to believe, but a relatively inexpensive remote-controlled shut-off switch, might have prevented the horrific oil spill into the Gulf of Mexico as well as the loss of 11 lives. It seems that the Minerals Management Service (MMS) encourages but does not require deepwater rigs to have backup systems to trigger the blowout preventers. The MMS allowed BP to delay the testing of the blowout preventer because of problems with well control. When they finally tested the blowout preventer (this is supposed to be done every two weeks), it was tested at a lower pressure than is federally required, 6,500 pounds per square inch rather than 10,000 pounds per square inch. There is also concern that BP increased the risk of an accident by using a cheaper type of well casing. There are also questions as to whether tests were done on the quality of the cement work performed by contractors. Ken Salazar, the Interior Secretary, observed that "oil companies have a history of running the show at the agency" (Urbina, 2010c, p. A18).

In the financial industry, enormous bonuses encouraged executives to take risks with other people's money. Without doubt, the compensation practices in the financial industry, which encouraged excessive risk taking, contributed greatly to the financial crisis. By securitizing the subprime mortgages, the risk was shifted to others. Bankers and mortgage brokers kept giving out mortgage loans to people who could not afford them so they could earn huge bonuses. It is for this reason that the European Union is placing caps on bonuses paid to bankers - no more than $30 \%$ of a bonus in cash - in order to reduce excessive risk taking (Alderman, 2010). The rest of the bonus will be held back for three years to determine whether the profits are real or illusory. As we learned in 2008, the huge bonuses paid to bankers and other executives were not real. It became clear that the financial institutions were holding debt that had very little value. To make matters worse, financial institutions such as Bear Stearns were so highly leveraged that they had no financial cushion to withstand a crisis. It is not surprising that many banks and other companies ended up in bankruptcy.

Cohan (2008) feels very strongly that compensation reform in Wall Street is badly needed. He feels that the change from the old system where the big firms (e.g., Donaldson, Lufkin, and Jenrette; Merrill Lynch; Morgan Stanley; Goldman Sachs; Lazard; etc.) switched from being a partnership to a public company contributed to the financial debacle. When these firms were partnerships, there was collective liability; firms were much more cautious. Once they became corporations with common stock, "bankers and traders were encouraged to take short-term risks with shareholder's money" (Cohan, 2008, p. 13). These bankers and traders did not mind taking on more and more risk since their bonuses depended on the annual profits. They were using other people's money to become super wealthy. Siegel (2009) feels that the CEOs deserve most of the blame for the financial crisis. He also makes the point that when the major investment banks such as Lehman Brothers and Bear Stearns were partnerships, they were much more conservative since they were risking their own money. This all changed once they became public companies. Put these ingredients together - excessive risk taking, lack of accountability, and use of shareholder's money - and you get a financial meltdown.

What happened to Fannie Mae and Freddie Mac demonstrates the dangers of taking on too much risk. In 2000, Fannie Mae, under CEO Franklin D. Raines and CFO J. Timothy Howard decide to expand into riskier mortgages. They would use sophisticated computerized mathematical models and rank borrowers according to the risk level of the loan; the riskier the loan, the higher the fees that would be 
charged to guarantee the mortgage. They felt that the computer models would ensure that the higher fees for the riskier mortgages would offset any losses from mortgage defaults. The company announced that it would purchase \$2 trillion in loans from low-income (and risky) borrowers by 2010 (Duhigg, 2008). What this accomplished - besides enriching the executives at Fannie Mae - was that it made subprime mortgages, which in the past would have been avoided by lenders, more acceptable to banks all over the country. These banks did not have the sophistication or experience to understand the kind of risk they were taking on. Between 2001 and 2004, the subprime market grew from $\$ 160$ billion to $\$ 540$ billion (Duhigg, 2008).

As early as February 2003, Armando Falcon, Jr., who ran the Office of Federal Housing Enterprise Oversight (OFHEO), wrote a report that warned that Fannie and Freddie could default because they were taking on far too many mortgages and did not have the capital to protect themselves against losses. Falcon almost got fired for this report. In 2004, allegations of accounting fraud surfaced at Freddie and Fannie; both had to restate earnings. Daniel H. Mudd became CEO of Fannie Mae in 2005 after Raines and Howard resigned from Fannie Mae under a cloud of accusations. Under Mudd's watch, Fannie purchased even riskier mortgages-mortgages that were so new that the computer models could not analyze them properly. Mr. Mudd was warned by Enrico Dallavecchia, his chief risk officer, that the company was taking on too much risk and should charge more. According to Dallavecchia, Mudd's response was that "the market, shareholders, and Congress all thought the companies should be taking more risks, not fewer. Who am I supposed to fight with first?" (Duhigg, 2008, p. A34). In September, 2008, the Federal government had to take over Fannie Mae and Freddie Mac. They had taken on far too much risk, and were in serious trouble.

Crouhy (2010), in a discussion of risk management failures in the financial crisis, considers that the risk models (e.g., VaR) were extremely simple and not meant to describe complex financial instruments. Another problem was that there was almost no consideration of the consequences of liquidity risk. Firms were too leveraged and took spectacular risks with very little equity. Crouhy posits that risk models and improper risk assessment were the root cause of the financial crisis, compounded by overreliance on deceptive ratings of the credit rating agencies. Today we know that the AAA ratings given to collateralized debt obligations were ludicrous. These were extremely risky securities and deserved a much lower rating. How AAA ratings could be given to securities that are basically junk is addressed in the next section.

\section{Conflict of Interest}

In the early 1970s, credit-rating agencies such as Moody's starting charging fees for their ratings. Before that, they never took money from the issuer of the debt. Revenues came from the investors who purchased the publications of the credit-rating agencies. The original business model recognized that to charge the issuer of the security for the rating would lead to the suspicion that ratings would be for sale, i.e., there could be a conflict of interest (Morgenson, 2008). By ingratiating themselves with clients, the credit rating agencies were able to steer more business to themselves. In fact, providing ratings for complex financial securities was much more lucrative than doing the same for simple bonds. For example, rating a complex $\$ 350$ million mortgage pool would generate approximately $\$ 250,000$ in fees; rating $\$ 350$ million of municipal bonds would only generate $\$ 50,000$ in fees.

It is interesting to note that, of the subprime mortgage backed securities that were issued in 2006 and rated AAA by the rating agencies, 93\% are currently rated as junk (Krugman, 2010a). Clearly, the conflict of interest has played a significant role in the corruption of the entire rating system. The rating agencies - Moody's, Standard \& Poor, and Fitch - knew that they would lose clients if their ratings were too tough. This is confirmed by emails sent by employees of the credit rating agencies that mention "the ongoing threat of losing deals" and the need to "massage the subprime and alt-A numbers to preserve market share" (Krugman, 2010a, p. A23).

Another ongoing investigation conducted by New York prosecutors is aimed at eight major banks. They are investigating how these banks "created, rated, sold and traded mortgage securities that turned out to be some of the worst investments ever devised" (Schwartz and Dash, 2010, p. B1). The answer, of course, also relates to conflicts of interest. Banks made a huge amount of money selling these 
garbage securities. Banking executives made huge bonuses and had little interest in investigating the true quality of these securities.

Washington Mutual (WaMu), which suffered the second largest bankruptcy in American history, failed largely because the bank approved mortgages to people with little income. They used adjustable rate mortgages (ARMs) to entice poor people to borrow money and approved almost every mortgage. The people obtaining the mortgages did not realize that the very low payments would not continue indefinitely and would eventually balloon. According to WaMu employees, CEO Kerry K. Killinger, put a huge amount of pressure on employees to lend money to borrowers who had little in the way of income or assets. Real estate agents were given fees of thousands of dollars for bringing borrowers to $\mathrm{WaMu}$, and WaMu gave mortgage brokers generous commissions for the riskiest loans since they produced higher fees and resulted in increased compensation for executives. Between 2001 and 2007, Killinger earned approximately $\$ 88$ million (Goodman and Morgenson, 2008). Clearly, the conflict of interest caused executives at WaMu to take on huge amounts of risk for his bank. These so called "misaligned incentives" encouraged foolhardy behavior. It is hard to act ethically when the bonuses are in the millions. The CEO was not risking his own money or his own house. The risk was borne by others; the bonuses went to him.

Bonuses made up a huge part of how people were compensated. These bonuses caused a huge conflict of interest. One individual at Merrill Lynch received $\$ 350,000$ as salary but $\$ 35,000,000$ as bonus pay. Bonuses were based on short-term profits; this distorted the way incentives work. Employees were encouraged to take huge risks since they were interested in the bonus, which were based on the earnings for that year. Thus, billions in bonuses were handed out by Merrill Lynch in 2006 when profits hit $\$ 7.5$ billion. Of course, those profits were only an illusion as they were based on toxic mortgages. The bonuses were not rescinded after the company lost billions. E. Stanley O'Neal, former CEO of Merrill Lynch, not only collected millions of dollars in bonuses but was given a package worth about \$161 million when he left Merrill Lynch.

A.I.G. Financial Products, a 377-person office based in London, nearly destroyed the mother company, a trillion-dollar firm with approximately 116,000 employees. This small office found a way to make money by selling credit default swaps to financial institutions holding very risky collateralized debt obligations. They made billions in bonuses selling super-risky garbage securities. Same story here: while they made a huge amount of money in bonuses; the risk was carried by the entire company.

Goldman Sachs has been accused by the Securities and Exchange Commission of selling mortgage securities that had virtually no chance of being successful. The mortgage bonds in the portfolio were allegedly selected by John A. Paulson, a hedge fund manager, who was betting against the mortgage market and would only make money if the securities failed (Story and Morgenson, 2010). Krugman (2010b, p. A23) calls what Goldman Sachs allegedly did as "looting." It takes a great deal of arrogance to develop and sell securities that are "deliberately designed to fail" so as to enable a valuable client to enrich himself from the failure. This goes far beyond what a number of Wall Street firms did in marketing securities to various naïve clients all over the world while trying to make exorbitant profits by betting that these risky, low-quality securities would drop in value. Goldman has agreed to pay a penalty of $\$ 550$ million, the largest settlement in the SEC history. The settlement may be large but the company will barely feel it; Goldman made profits of $\$ 13.39$ billion last year (Chan and Story, 2010).

Conflicts of interest are also a factor in the BP oil spill. The government has decided to divide the Minerals Management Service in two - one office would be concerned with environmental safety; the other, with collection of leasing revenues from the oil industry. The government believes that there were conflicts of interest since the same agency both collected revenues from drilling and was also responsible for environmental enforcement. Some countries separated the two functions, as did Britain after an oil rig accident 1988 (Zeller, 2010).

It is unmistakable that reducing or eliminating conflicts of interest will go a long way towards making it easier for people to behave ethically and prudently. Of course, politicians can work against conflicts of interest in the political realm. According to Lichtblau and Wyatt (2010), the financial industry, via 
political action committees and private donations, provided congressional candidates with more than $\$ 1.7$ billion in the last 10 years. A good part of these funds went to the financial committees that oversee financial regulation and are supposed to protect the public from dishonest financial practices. The energy industry is also doing its part in influencing legislators. The Office of Congressional Ethics is investigating eight members of Congress who received a considerable amount of money in contributions from the financial sector a few days before the House voted on a landmark bill to regulate the financial industry after the meltdown of 2008 (Lipton and Lichtblau, 2010). A significant portion of these contributions was received during a 10-day period before the crucial vote. A highly questionable practice involves corporations which attempt to influence politicians by financing university endowments - including endowed chairs, institutes, and academic centers - that honor those lawmakers (Lipton, 2010).

A general truism is that lapses in business ethics can always be traced back to an underlying conflict of interest. In the presence of such conflicts of interest as are discussed here, the invisible hand of an unregulated marketplace becomes just another mechanism for rampant self-interest and unmitigated greed.

\section{Deregulation}

Whether in Enron's creative accounting, the packaging of high-risk subprime mortgages as top-grade collateralized debt obligations, or Bernard Madoff's $\$ 50$ billion scam operation, the recent riot of capitalist irresponsibility has shattered the fantasy that the free market, left to its own devices, will produce rationality and prosperity (Phelps, 2009, p. B11).

Over the past several decades, many economists and politicians have encouraged the U.S. to move towards removing regulations. Regulations were seen as an obstacle towards free markets and, thus, deregulation was supposed to make the U.S. more innovative and successful. For example, the GlassSteagall Act of 1933 had separated commercial banking from investment banking. The purpose of this regulatory wall was to reduce risk in the banking system. The Glass-Steagall Act of 1933 was repealed in 1999.

The belief that the invisible hand of the marketplace - i.e., everyone pursuing his or her own self interest - is sufficient to ensure a stable and healthy economy, and that little or no government regulation is necessary, has been attributed to Adam Smith (1776). Robinson (2007) asserts that the single-minded pursuit of self-interest has caused much harm to society and that we should cease associating Adam Smith with this doctrine. In actuality, in the book he believed would establish his reputation, The Theory of Moral Sentiments, Smith made it clear that he believed that economic growth depended on morality. He said "society... cannot subsist among those who are at all times ready to hurt and injure one another." Smith $(1759 ; 2002: 162)$ argued that:

Man... ought to regard himself, not as something separated and detached, but as a citizen of the world, a member of the vast commonwealth of nature and to the interest of this great community, he ought at all times to be willing that his own little interest should be sacrificed.

To Smith, benevolence — not pursuit of self-interest — was one of the highest virtues (Pack 1991).

In 1937, at his second inaugural address, President Franklin D. Roosevelt said: "We have always known that heedless self-interest was bad morals; we know now that it is bad economics" (Roosevelt, 1937, para. 11). Lawrence H. Summers, now Director of President Barack Obama's White House National Economic Council, in a 2003 speech to the Chicago Economic Club, made the following remark:

For it is the irony of the market system that while its very success depends on harnessing the power of self-interest, its very sustainability depends upon people's willingness to engage in acts that are not self-interested (Summers, 2003, para. 19). 
Lowenstein (2008) points out that only six months after the Long Term Capital Management (LTCM) fiasco, then Chairman of the Federal Reserve Alan Greenspan "called for less burdensome derivatives regulation, arguing that banks could police themselves" (p. BU1). Long Term Capital Management, a hedge fund started in 1994 that went out of business in 2000, in 1998, had borrowed over \$125 billion, but only had equity of $\$ 5$ billion. The financial crisis started by LTCM at that time should have demonstrated how the entire financial system could be at risk because of the actions of one fund taking huge risks. Without the intervention of the Federal Reserve Bank and its $\$ 3.5$ billion rescue package, the entire financial market might have collapsed.

It appears that even Alan Greenspan, former Chairman of the Federal Reserve, changed his mind about unregulated capitalism. Suskind (2008) reports that Alan Greenspan, at a meeting on February 22, 2002 after the Enron debacle, was upset with what was happening in the corporate world. Greenspan noted how easy it was for CEOs to "craft" financial statements in ways that could deceive the public. He slapped the table and exclaimed, "there's been too much gaming of the system. Capitalism is not working! There's been a corrupting of the system of capitalism" (Suskind, 2008, p. A29). Unfortunately, despite what happened at Enron, Greenspan continued to believe in unregulated capitalism.

Alan Greenspan did finally admit at a congressional hearing in October 2008 that investigated the financial meltdown of 2008 that he had relied too much on the "self-correcting power of free markets" (Andrews, 2008, p. B6). Greenspan also acknowledged that he did not anticipate the "self-destructive power of wanton mortgage lending" (Andrews, 2008, p. B6). When asked whether his ideology - i.e., belief in deregulation and that government regulators did not do a better job than free markets in correcting abuses - contributed to the financial crisis, he admitted that he had made a mistake and actually took partial responsibility. The mistakes to which Greenspan referred related to the sub-prime mortgages and out of control derivatives market. One hopes that there are very few economists out there that still believe that financial markets can regulate themselves.

The market for derivatives and credit default swaps (CDSs) became unregulated thanks to the Commodity Futures Modernization Act of 2000, which was pushed by the financial industry in the name of free markets and deregulation. The law also made it virtually impossible for states to use their own laws to prevent Wall Street from doing anything about these financial instruments. This bill was passed "at the height of Wall Street and Washington's love affair with deregulation, an infatuation that was endorsed by President Clinton at the White House and encouraged by Federal Reserve Chairman Alan Greenspan" (Kroft, 2008).

Eric Dinallo, the insurance superintendent of New York State, had the following to say regarding credit default swaps (Kroft, 2008):

As the market began to seize up and as the market for the underlying obligations began to perform poorly, everybody wanted to get paid, had a right to get paid on those credit default swaps. And there was no 'there' there. There was no money behind the commitments. And people came up short. And so that's to a large extent what happened to Bear Sterns, Lehman Brothers, and the holding company of AIG. It's legalized gambling. It was illegal gambling. And we made it legal gambling... with absolutely no regulatory controls. Zero, as far as I can tell.

In response to the question as to whether the CDSs market was like a "bookie operation," Dinallo said: "Yes, and it used to be illegal. It was very illegal 100 years ago."

Other steps were taken to reduce regulation of the banking system. On April 28, 2004 there was a meeting between five major investment banks and the five members of the S.E.C. The investment banks wanted an exemption from a regulation that limited the amount of debt - known as the net capital rule - they could show on their balance sheets. By increasing the amount of debt, they would be able to invest in the "opaque world of mortgage-backed securities" (Labaton, 2008, p. A23) and credit default swaps (CDSs). The S.E.C. agreed to loosen the capital rules and also decided to allow the investment banks to monitor their own riskiness by using computer models to analyze the riskiness of various securities, i.e., switch to a voluntary regulatory program (Labaton, 2008). The firms did act on the new requirements and took on huge amounts of debt. Thus, the leverage ratio at Bear Stearns 
rose to 33:1; this made the firm very risky since it held only $\$ 1$ of equity for $\$ 33$ of debt. Regarding what transpired, Professor James D. Cox, an expert on securities law and accounting at Duke, said:

We foolishly believed that the firms had a strong culture of self-preservation and responsibility and would have the discipline not to be excessively borrowing ... Letting the firms police themselves made sense to me because I didn't think the S.E.C. had the staff and wherewithal to impose its own standards and I foolishly thought the market would impose its own self-discipline. We've all learned a terrible lesson (Labaton, 2008, p. A23).

President George W. Bush wanted to encourage homeownership, especially among minorities. Unfortunately, his approach, which encouraged easy lending with little regulation, helped contribute to the financial crisis (Becker, Stolberg, and Labaton, 2008). The increase in homeownership was accomplished through the use of toxic mortgages. President Bush also encouraged mortgage brokers and corporate America to come up with innovative solutions to enable low-income people to own homes. Various states, at one point, did try to enact legislation against predatory lending but were blocked by the Federal government. The attorney general of North Carolina said: "They took 50 sheriffs off the beat at a time when lending was becoming the Wild West" (Becker, Stolberg, and Labaton, 2008, p. 36).

Amartya Sen's 2010 commencement speech to students of St. Michael's College might very well sum up how many economists feel about deregulation today. The Nobel laureate stated the following: "A well-functioning market economy can make a huge contribution to the growth of incomes and living standards. In the absence of sensible regulations, the market can also yield a complete disaster" (Dillon, 2010, p. A22).

Similarly, in the offshore oil drilling industry, Federal regulators appear to have failed to properly oversee drilling in the Gulf. The April 20, 2010 Deepwater Horizon blowout, even worse than the Exxon Valdez oil spill of 1989, poured huge quantities of oil into the Gulf of Mexico. It is another consequence of trusting companies to do a good job of regulating themselves. It is becoming clear that the Minerals Management Service (MMS) which is supposed to protect the environment did not do its job well. In fact, a huge scandal is unfolding at the Minerals Management Service involving corruption, sex, and drugs. This agency of the Interior Department, accused of having a "culture of substance abuse and promiscuity," did not adequately protect the environment (Savage, 2010, p. A1). Another scandal that is coming to light regarding the MMS is that it has allowed numerous oil companies to drill all over the Gulf of Mexico without obtaining the required permits from the other agencies - e.g., the National Oceanic and Atmospheric Administration (NOAA) - whose job it is to assess the environmental impact of drilling. Indeed, it appears that the MMS routinely ignored warnings of their own engineers and biologists regarding safety and environmental issues. Scientists working for MMS are claiming that they were routinely pressured into changing any reports that indicated that drilling could lead to an environmental mishap (Urbina, 2010a, 2010b). It is becoming evident that the entire system of regulating offshore drilling needs to be overhauled. The MMS has approximately 60 inspectors to oversee 4,000 offshore oil facilities in the Gulf. Clearly, more inspectors are needed. The MMS encouraged the offshore oil rigs to have backup systems to activate the blowout preventers. However, there was no enforcement (Belsie, 2010).

Abraham (2010, p. A27) calls the gulf oil spill "a disaster Congress voted for." Congress encouraged more drilling for oil back in 1995 by reducing its share of the proceeds from oil and gas drilling. The additional money going to the offshore drillers was supposed to encourage them to find more oil. Congress did indeed encourage more drilling, and at the same time reduced the staff needed to regulate the industry, despite the fact that drilling in deeper water posed additional risks. In fact, the 2001 President's National Energy Policy directed the agencies to eliminate regulations that were supposedly - "excessive and redundant" (p. A27).

One would hope that these two mega-disasters affecting the financial system and the environment should put to rest once and for all the myth that markets can regulate themselves and that, therefore, no government regulation is necessary. There is no question that regulation is needed. Of course, this does not mean that government should overdo it with regulations. Too much regulation can stifle 
innovation but a reasonable amount of regulation can ensure that markets function in a fair way and spread prosperity to all.

Savitz and Weber (2006) use the example of the whaling industry as a symbol to show what happens when companies pursue profits without considering the "triple bottom line," which considers an organization's success to be based on economic, environmental, and social performance, ${ }^{2}$ rather than only profit. The whaling industry once employed 70,000 people and was an important American industry. It began to decline in the mid-1840s when the number of whales dropped precipitously because the firms did not consider the future, and only were concerned with current profits. Savitz and Weber $(2006$, p. x) state: "a sustainable corporation is one that creates profits for its shareholders while protecting the environment and improving the lives of those with whom it interacts." Unfortunately, most companies do not think this way and we are seeing many examples of firms that are not interested in the triple bottom line. In fact, overfishing is still causing problems in many countries; this is one reason why regulation is necessary.

Whenever a resource is held in common by a group of individuals, it will always be in the interest of each individual to exploit the resource. The tragedy is that eventually the resource will be completely depleted. For instance, if a forest is community property, everyone in town will keep logging it until the forest has been totally consumed. This problem is known as the "tragedy of the commons," a term coined by Hardin (1968). That is another example of a situation where regulation is necessary.

Warner (2010) feels that we should be called a "nation of dysregulation." After seeing the effects of the

...failure of the levees during Hurricane Katrina, the Wall Street meltdown of 2008, the collapse of the housing market and now the BP spill, we have come to what feels like a moment of reckoning, with some tentative signs that our country's decades-long love affair with deregulation is starting to chill ( $p .11)$.

A majority of Americans believe that a weak regulatory system is the major cause of the BP spill (Warner, 2010). Dr. Peter Whybrow, Director of the Semel Institute for Neuroscience and Human Behavior, feels that living in a culture of overindulgence, compulsive getting, need for instant gratification, and hyperconsumption has weakened our self-regulatory system. This "orgy of selfindulgence" is responsible for the obesity epidemic in the U.S.as well as the willingness to go into excessive debt to purchase homes and products we cannot really afford (Warner, 2010). It is interesting that researchers are connecting the problem of lack of self-regulation with the overall issue of deregulation.

Rogoff (2010) makes the comparison between the BP oil spill and the financial crisis. Both, in his opinion, demonstrate how, when technology (or financial instruments) is very complex, it becomes almost impossible to adapt regulation. This means that government will either regulate too much or too little. After all, regulators cannot keep changing the rules even if technology is constantly evolving. Rogoff also states: "Economics teaches us that when there is huge uncertainty about catastrophic risks, it is dangerous to rely too much on the price mechanism to get incentives right" (para. 13).

\section{Conclusion}

Risk, conflicts of interest, and deregulation. These are the common elements that conspired to create the synchronicity of these two current mega-crises - the financial meltdown and subsequent recession and the BP oil catastrophe. One obvious important lesson to be learned is that greed is not good. It should now be apparent that unbridled greed was responsible for both debacles, which provide us with valuable insights into the proper way to run an economy.

Another overarching lesson is that firms have to maintain a culture of social responsibility. Corporate social responsibility means that firms have to focus on more than simply maximizing shareholder

2 Sometimes referred to as the three P's - people, planet, and profit. 
wealth. One definition of corporate social responsibility (CSR) is cited in Hollender and Fenichell (2004, p. 29):

... an ongoing commitment by business to behave ethically and to contribute to economic development when demonstrating respect for people, communities, society at large, and the environment. In short, CSR marries the concepts of global citizenship with environmental stewardship and sustainable development.

Corporate social responsibility is often a broader and richer concept than business ethics alone. It certainly includes business ethics but also takes into account such concepts as helping one's community and global citizenship. Lantos (2001) asserts that there are three types of CSR: ethical, altruistic, and strategic. One can argue against altruistic CSR since helping others can reduce the profits of the firm and thus hurt the shareholders. Strategic CSR focuses on doing good in a way that benefits the firm. Ethical CSR, which is concerned with avoiding societal harm, is something that all organizations must advocate.

Today's twin mega-crises teach us that it is vital to minimize conflicts of interest in order to encourage executives to behave in an ethical manner. Secondly, firms must consider risk in decision making. These risks should include possible harm to the environment, employees, customers, the United States, the world, and, of course, shareholders. By removing or reducing conflicts of interest, it becomes much less likely that executives will engage in extremely risky behaviors.

With a sole proprietorship, the owner is less likely to take excessive risks that could result in the loss of one's family business and home. With a corporation, especially when there are obvious conflicts of interest, it is unlikely that an executive will not take unwarranted risks. Would a banker take a one in a million chance of destroying the livelihood of thousands of employees to make a definite $\$ 50$ million bonus? How about a one in a million chance of destroying the world financial system and millions of jobs for a sure $\$ 300$ million bonus? Do we even want executives to make those decisions?

It is unfortunate that self-regulation does not usually work. The greed motive is often too strong. Many industries work within the constraints of various regulations and prosper. There are codes and guidelines for every construction project in the United States. Would you want your children to drive a car over a bridge that was not built to code? Fly in a jet that does not abide by FAA safety guidelines? For those who feel government regulation is totally unnecessary, note how many dangerous products have recently come out of China. These include toys with dangerous amounts of lead, poisonous pet food, flammable baby clothes, tainted sea food, poisonous toothpaste, adulterated dairy products, and much more. In fact, according to a European Union report, China was the source of most dangerous products (New York Times, 2008). China is now in the process of strengthening regulation of its products. The Avandia diabetes drug saga also demonstrates that many firms cannot be trusted to report unfavorable statistical findings when it will affect profits. It appears that GlaxoSmithKline, the manufacturer of Avandia, purposely suppressed results that indicated that the drug was riskier for the heart than a competing drug for diabetics. An email message sent by an executive cautioned someone to make sure that "these data should not see the light of day" (Silverman, 2010, para. 2).

Warren Buffett once said that "It takes 20 years to build a reputation and five minutes to ruin it." The twin mega-crises have shown us how true this is. Think of what has happened to the stellar reputations of such firms as BP, Goldman Sachs, Fannie Mae, Freddie Mac, AIG, Merrill Lynch, and others. It is not only reputation that has diminished. BP lost many billions of dollars of market value (at one point $\$ 70$ billion) because of the market crisis, and there is a strong possibility that it will be taken over by another firm once the crisis is over (Winston, 2010). The reputation of Goldman Sachs has been ruined. It has been described by Rolling Stone magazine as "a great vampire squid wrapped around the face of humanity" (Taibbi, 2010, para. 1).

... And once we thought that no one could sink lower than Enron. 


\section{References}

Abraham, D. S. (2010, July 14). A disaster congress voted for. New York Times, p. A27.

Adams, D. (1992). Mostly Harmless (Hitchhiker's Trilogy, No. 5). NY: Random House.

Alderman, L. (2010, July 24). Europe caps pay at banks to curb risk. New York Times, pp. B1, B11.

Andrews, L. (2008, October 24). Greenspan concedes error on regulation. New York Times, pp. B1, B6.

Becker, J., Stolberg, S. G. and Labaton, S. (2008, December 21). White House philosophy stoked mortgage bonfire. New York Times, pp. A1, A36-37.

Belsie, L. (2010, July 10). Six lessons from the BP oil spill. Christian Science Monitor, Retrieved from http://www.csmonitor.com

Chan, S. and Story, L. (2010, July 16). S.E.C. settling its complaints with Goldman. New York Times, pp. A1, B8.

Cohan, W. D. (2008, November 16). Our risk, Wall Street's reward. New York Times, Week in Review, p. 13.

Crouhy, M. (2010). Risk management failures during the financial crisis. In R. W. Kolb (Ed.) Lessons from the financial crisis: Causes, consequences, and our economic future (pp. 283 - 291). Hoboken, NJ: John Wiley \& Sons.

Dillon, S. (2010, June 21). Wisdom of leaders, dreamers and an expert at kissing. New York Times, p. A22.

Duhigg, C. (2008, October 5). Pressured to take more risk, Fannie reached a tipping point. New York Times, pp. A1, A34.

Goodman, P. S. and Morgenson, G. (2008, December 28). By saying yes, WaMu built empire on shaky loans. New York Times, pp. 1, 22.

Hardin, G. (1968), "The Tragedy of the Commons," Science, 162, pp. 1243-1248.

Hollender, J. and Fenichell, S. (2004). What matters most. New York: Basic Books.

Kroft, S. (2008, October 26). The bet that blew up Wall Street. 60 Minutes, retrieved from http://www.cbsnews.com/

Krugman, P. (2010a, April 26). Berating the raters. New York Times, OP-ED, p. A23.

Krugman, P. (2010b, April 19). Looters in loafers. New York Times, OP-ED, p. A23.

Labaton, S. (2008, October 3). Agency's '04 rule let banks pile up new debt and risk. New York Times, pp. A1, A23.

Lantos G. P. (2001). The boundaries of strategic corporate social responsibility. Journal of Consumer Marketing 18 (7): 595-632.

Lichtblau, E. and Wyatt, E. (2010, May 23). Financial bill poses big test for lobbyists. New York Times, pp. 1,15.

Lipton, E. (2010, August 6). Lawmakers linked to centers endowed by corporate money. New York Times, p. A1+.

Lipton, E. and Lichtblau, E. (2010, July 15). Fund-Raising before house vote on a financial overhaul draws scrutiny. New York Times, p. A19.

Lowenstein, R. (2008, September 7). Long-Term Capital Management: It's a short term memory. New York Times, p. BU1.

Lyall, S. (2010, July 13). In BP's record, a history of boldness and blunders. New York Times, pp. A1, A14.

Morgenson, G. (2008, December 7). Debt watchdogs: Tamed or caught napping. New York Times, pp. $1,40$.

Mouawad, J. (2010, May 8). For BP, a history of spills and safety lapses. New York Times, Business Day, p.A22. Retrieved from http://www.nytimes.com

New York Times (2008, April 17). China is source of the most dangerous products, EU report says. NYTimes.com. Retrieved from http://www.nytimes.com/

Pack, S. J. (1991). Capitalism as a moral system: Adam Smith's critique of the free market economy. Aldershot, UK: Edward Elgar Publishing.

Phelps, Christopher (2009, February 13). Beyond economic revival: Which New Deal approaches are worth emulating? Chronicle Review, pp. B10-B12. 
Robertson, C. and Krauss, C. (2010, August 3). Gulf spill is the largest of its kind, scientists say." New York Times, p. A14.

Robinson, J. (2007). "Morality and economics." Economist's View. Retrieved from http://economistsview.typepad.com/

Rogoff, K. (2010, June 1). The BP oil spill's lessons for regulation. Project Syndicate. Retrieved from http://www.project-syndicate.org/

Roosevelt, F. D. (1937). Second Inaugural Address. Retrieved from http://www.bartleby.com/

Savage, C. (2010, September 10). Sex, drug use and graft cited in interior department. New York Times, pp. A1+. Retrieved from http://www.nytimes.com

Savitz, A. W. and Weber, K. (2006). The triple bottom line. San Francisco, CA: Jossey-Bass.

Schwartz, N. D. and Dash, E. (2010, May 14). With banks under fire, some expect a settlement. New York Times, pp. B1, B3.

Siegel, J. (2009, January 21). Lesson one: What really lies behind the financial crisis. Knowledge@Wharton. Retrieved from: http://knowledge.wharton.upenn.edu/

Silverman, E. (2010, July 13). Glaxo hid a study on Avandia risks for a decade. Pharmalot. Retrieved from http://www.pharmalot.com/2010/07/glaxo-hid-a-study-on-avandia-risks-for-a-decade/

Smith, A. (1759, 2002). The theory of moral sentiments. (Edited by Knud Haakonssen.) Cambridge: Cambridge University Press.

Smith, A. (1776). The Wealth of Nations.

Story, L. and Morgenson, G. (2010, April 17). S.E.C. accuses Goldman of fraud in housing deal. New York Times, pp. A1, B6.

Summers, L. H. (2003, October 14). Remarks of Harvard University President Lawrence H. Summers at the Chicago Economic Club. Retrieved from http://www.hks.harvard.edu/

Suskind, R. (September 25, 2008). "The crisis last time." New York Times, p. A29.

Taibbi, M. (2010, April 5). The great American bubble machine. Rolling Stone. Originally published July 2009. Retrieved from http://www.rollingstone.com/

Taleb, N. N. (2010). The black swan: The impact of the highly improbable. New York: Random House.

Urbina, I. (2010a, May 14). U.S. said to allow drilling without needed permits. New York Times, pp. A1, A12.

Urbina, I. (2010b, May 27). BP chose casing options believed to carry risks. New York Times, pp. A1, A20.

Urbina, I. (2010c, June 6). At issue in Gulf: Who was in charge. New York Times, pp. A1, A18- A19.

Warner, J. (2010, June 20). Dysregulation nation. New York Times Magazine, pp. A11-A12.

Winston, A. (2010, June 3). Five lessons from the BP oil spill. Harvard Business Review Blogs. Retrieved from blogs.hbr.org/winston/2010/06/the-bp-oil-spill-top-5-lessons.html

Zeller Jr., T. (2010, May 12). Mineral agency's split follows nations' lead. New York Times, p. A15. 